Marquette University

e-Publications@Marquette

$10-1-1981$

\title{
Industrial Design: On Its Characteristics and Relationships to the Visual Fine Arts
}

Curtis Carter

Marquette University, curtis.carter@marquette.edu

Published version. Leonardo, Vol. 14, No. 4 (Fall 1981): 283-289. DOI. (C) 1981 Massachusetts Institute of Technology Press (MIT Press). Used with permission. 


\title{
INDUSTRIAL DESIGN: ON ITS CHARACTERISTICS AND RELATIONSHIPS TO THE VISUAL FINE ARTS
}

\author{
Curtis L. Carter*
}

\begin{abstract}
Industrial design and the visual arts share a common aesthetic basis as demonstrated by their common use of aesthetic principles and by designers who are also visual artists. The author examines the rationale for exhibiting industrial products in art museums and the similarities and differences between industrial design and the fine arts. He argues that industrial design shares important theoretical concepts (expression, representation and style) with the visual fine arts.
\end{abstract}

\section{INTRODUCTION}

Visual artists have attempted to interpret industry in various ways for quite a long time. In the 20th century, for example, the Italian futurists Balla and Russolo and the painters Léger and Picabia in France introduced machine elements and interpretations of power and speed provided by machines into their artworks; Duchamp exhibited Ready-mades, such as an ordinary shovel bearing his signature, and some artists have exhibited imaginary machines as sculpture. During this period artists also found a new role as industrial designers. More recently, artists, for example in the U.S.A. those such as Jack Burnham, Frank J. Malina and many others, entered into projects that involve the collaboration of artists and engineers. Parallel to these developments is the practice of exhibiting industrial products designed for functional purposes in fine art museums of several countries. These three converging developments, which I shall refer to as industrial design and its relations to the visual fine arts, have been given little attention by aestheticians. The intent of this article will be to demonstrate that the visual arts and industrial design share a common aesthetic basis. This basis, however, does not imply a complete assimilation of one to the other, nor the acceptance of a division between the aesthetic and the practical, as was done, for example by Immanuel Kant [1].

My interest in the aesthetic questions posed by industrial products was intensified by the Art and Industry Exhibition that I prepared in 1979 for Marquette University. It consisted of industrial products from 36 companies in the U.S.A. and was devoted to the transport of materials, consumer

\footnotetext{
*Aesthetician, Dept. of Philosophy, Charles L. Coughlin Hall, Marquette University, Milwaukee, WI 53233, U.S.A. (Received 11 Feb. 1980)
}

goods and people [2]. It was divided into two parts, an outdoor exhibit of trucks, automobiles, recreational vehicles and farm and construction equipment (Fig. 1) and an indoor exhibit of smaller products, for example of engines, control and processing equipment, etc. (Fig. 2). The indoor exhibit also included displays of design drawings and models to explain the design process and mode of operation of the products and an original 55 minute sound 'collage' by composer Yehuda Yannay entitled 'Milwaukee Brew Project', based on sounds in industrial environments.

The products in the outdoor and indoor exhibits were arranged loosely into functional groupings according to their features of shape, scale and color into the following eight divisions: construction machinery, service vehicles, recreational vehicles, agricultural machines, electric motors and generators, machine components, electric controls (Fig. 3) and accessories. A monumental $75,000 \mathrm{~kg}$ red-orange colored earth excavator made by Koehring

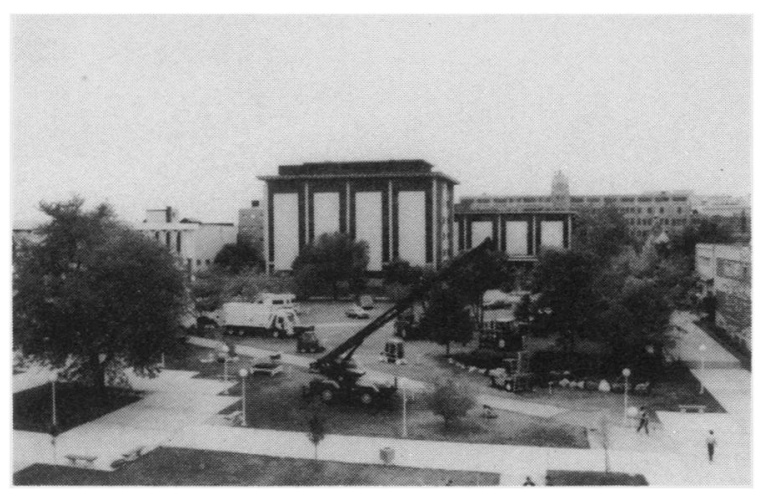

Fig. 1. View of outdoor exhibit of vehicles at the 'Art and Industry: The Art of Industrial Design' exhibition, Marquette University, Milwaukee, Wisconsin, U.S.A., 1979. (Photo: A. Lovinescu, Shorewood, WI, U.S.A.) 


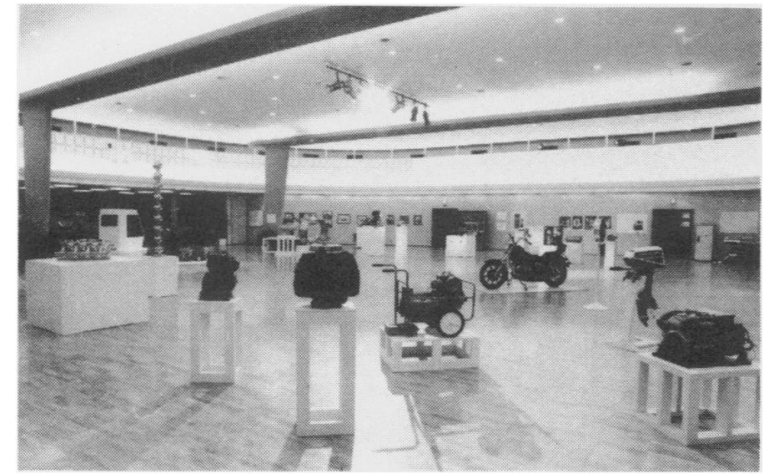

Fig. 2. View of indoor exhibit of industrial products. (Photo: A. Lovinescu, Shorewood, WI, U.S.A.) (See Fig. 1)

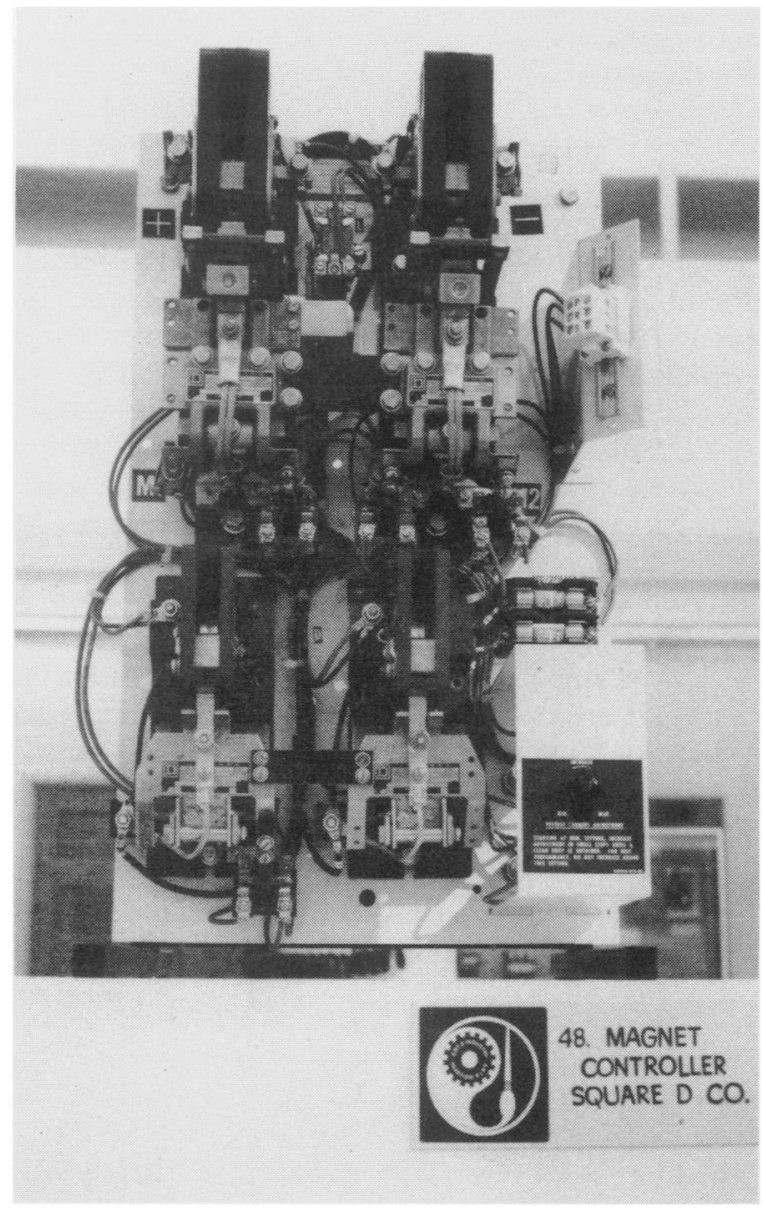

Fig. 3. View of magnet controller, produced by the Square D.Co., Milwaukee, WI, U.S.A. (Photo: A. Lovinescu, Shorewood, WI, U.S.A. (See Fig. 1)

(Fig. 4) formed an arch over an entry way to the outdoor exhibit, where the custom-built sports car 'Excalibur', designed by Brooks Stevens (Fig. 5), was juxtaposed against the recently designed starkly white garbage truck made by the Heil Company (Fig. 6). In the indoor exhibit, stainless steel

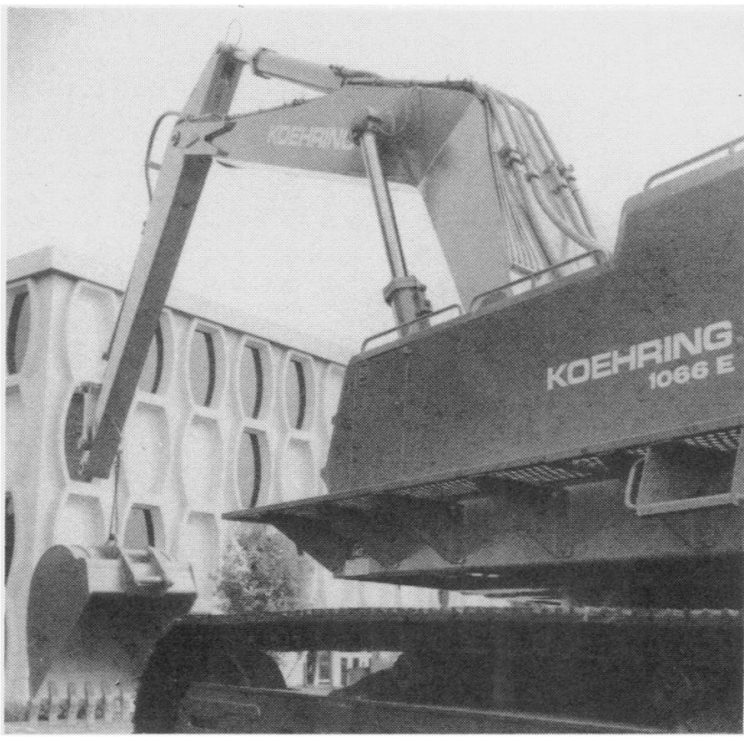

Fig.4. View of earth excavator produced by the Koehring Co., Milwaukee, WI, U.S.A., at an entry way to the Exhibition. (See Fig. 1)

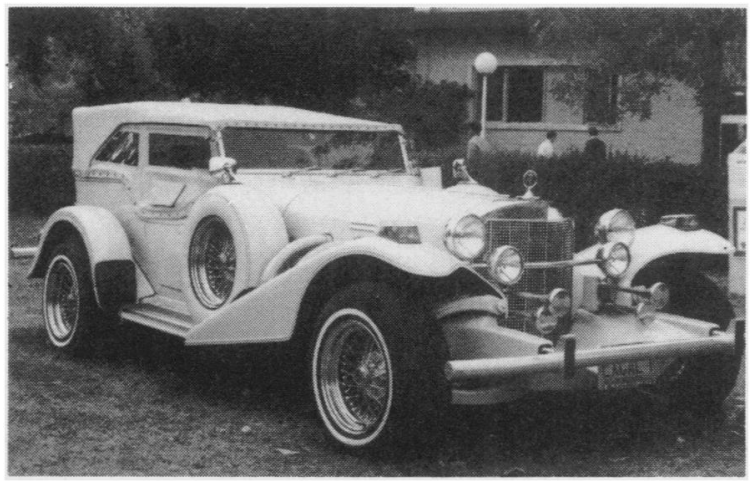

Fig. 5. View of the automobile 'Excalibur' designed by Brooks Stevens (Photo: A. Lovinescu, Shorewood, WI, U.S.A.) (See Fig. 1)

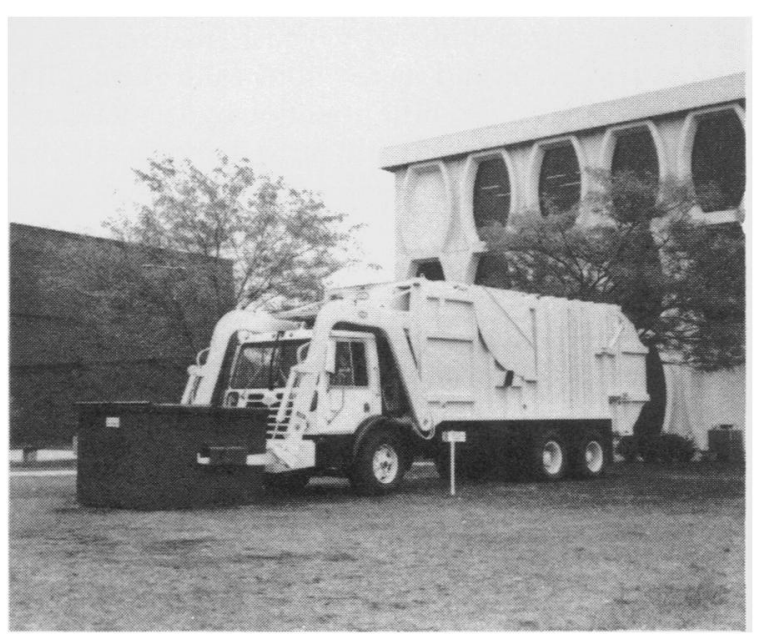

Fig. 6. View of the garbage truck produced by the Heil Co., Milwaukee, WI, U.S.A. (Photo: A. Lovinescu, Shorewood, WI, U.S.A.) (See Fig. 1) 
processing arteries made by Ladish vied for attention with the gray-colored electric motors and generators from the Louis Allis Co.

A survey of museum catalogues of industrial design exhibitions in the U.S.A. from the 1920s to the 1980s showed that a relatively narrow range of objects such as chairs, lamps, cameras, typewriters, clocks and automobiles were displayed. In contrast to earlier exhibitions of industrial products in museums, which had been influenced by the Bauhaus approach, no attempt was made to select products possessing either 'precious' or 'the most unique' design features. Priority was given to the suggestions of manufacturers to present what they considered relevant.

The Marquette exhibition of industrial products gave priority to their aesthetic characteristics involving form and color. Simple white pedestals were used to support smaller products, and the larger products were exhibited free standing. Museumtype signs were used to identify the products and their makers.

The intent of the exhibition was to examine the relation of visual fine art to contemporary industrial products. It raised for discussion such questions as these: Who are the visual artists in industry in the U.S.A.? What features of industrial products warrant their display in an art exhibition? What has been the contribution of visual artists to the design of industrial products? What is the present state and the future of industrial design?

Lectures and symposia to consider these questions were held in conjunction with the Exhibition. Jack Burnham, sculptor and art critic, presented a paper entitled Engineering and Avant Garde Art in which he traced the development of works by artists in the U.S.A. involving 20th century engineering concepts. His study might lead industries to make more use of visual artists. Composer Yehuda Yannay gave a paper entitled Industrial Sounds and New Music. He told how he had used sounds recorded in industrial settings to make the sound 'collage' commissioned for the Exhibition, and he discussed the need to take into account the problems of undesirable noise in industrial processes. Industrial designers Brooks Stevens and William Porter represented the industrial design profession. Stevens, who also served as guest consultant for the Exhibition, spoke on The Relation of Art to Industry from the perspective of a free-lance industrial designer. He emphasized the importance of the aesthetic qualities of products. Porter, a designer for the General Motors Corp., discussed the industrial designer's role as a member of the corporate team. Both of them noted the importance of their training in architecture (Stevens) and painting (Porter) for their work in industrial design. Porter, Stevens and Yannay were joined by Philip Lewis, landscape architect at the University of Wisconsin-Madison, and Jack Waldheim, teacher of design at the University of Wisconsin-Milwaukee, in a symposium entitled Art and Industry: Designing for the Future.

\section{A RATIONALE FOR EXHIBITING INDUSTRIAL OBJECTS AS ARTWORKS}

Industrial products are periodically, though not frequently, exhibited in art museums. In Great Britain, the British Institute of Industrial Art, founded in 1914, organized exhibitions and established a modest permanent collection of industrial products at the Victoria and Albert Museum, and there are earlier precedents [3]. Philip Johnson's exhibition entitled Machine Art at the New York City Museum of Modern Art in 1934 [4] marked the beginning in the U.S.A. of critical and public recognition that industrial products can be exhibited for their aesthetic qualities. There have been subsequent exhibitions at the Museum of Modern Art and elsewhere. Nevertheless nearly 50 years after Johnson's exhibition at the Museum of Modern Art the permanent display of selected industrial products there remains miniscule. An exhibition of industrial products in an art museum continues to puzzle many visitors, artists and scholars of art, and agencies in the U.S.A. that provide funds to art museums question the value of such exhibitions on the grounds that they lack artistic significance.

The painter Ad Reinhardt asserted, for example, that the function of an art museum is to preserve visual fine art only. "Any disturbance of the museum's soundlessness, airlessness, and lifelessness is a disrespect' [5]. I contend, however, that many industrial products are suitable for display in museums because of their family resemblance to some artworks and because their appearance is also often based on aesthetic considerations. I shall note important differences that separate fine art and industrial design.

In order to establish the rationale for exhibiting industrial products in fine art settings, without compromising either an institution or the products, it is necessary to examine first the emergence of the discipline of industrial design. Uncertainties over the designation of those who design in particular the exterior appearance of industrial products was resolved in the U.S.A. early in this century by adopting the special term industrial designer. Consciousness of a missing aesthetic factor in the exterior appearance of industrial products led to a new role for visual artists. They were invited, or chose, 'to go into the factories' to participate in the design of products. One of the first to be called an industrial designer was Peter Behrens, who was hired in 1907 by a company in Germany to serve both as architect and graphic designer [6]. Among the pioneers of industrial design in the U.S.A. in the 1930s were Walter Dorwin Teague, Henry Dreyfuss, Norman Bell Geddes and Raymond Loewy. They came from backgrounds in theatrical design and architecture, and they affected the exterior appearance of automobiles, trains, steamships, clocks, thermostats and numerous other objects [7].

One view of industrial design was that it was concerned with ornament or decoration to be applied to a product to make it more visually 
appealing after its engineering design had been determined [8]. This view closely resembles the ornamental approach to craft in the 19th century [9], and fell into disrepute because of the demands of mass production.

The other view of industrial design is that a designer must begin to work concurrently with product engineers, material specialists and marketing experts [Ref. 3, p. 28]. The dominant aesthetic of this approach to industrial design, one which incorporated traditional ideas of beauty (order, harmony, balance, proportion, unity and simplicity), was functionalism, which frequently led to machineinspired values such as precision, smoothness, reproducibility and economy [3, p. 227 and 4, p. 5]. Suitability for use, good materials, good workmanship and innovative structural and visual design were the goals of well designed products.

The practice of industrial design along the lines of functionalism led the early 20 th century practitioners to become aware of the need to explain the new discipline. Gilbert Seldes defined industrial design as the application of taste and logic to the products of machinery [10]. Dreyfuss said that industrial design is a means of making sure the machine created attractive commodities that work better because they are designed better. It is coincidental, but equally important', he adds, 'that they sell better' $[10$, p. 21$]$.

Recently the International Congress of Societies of Industrial Design adopted the following description of an industrial designer: 'One who is qualified ... to determine the materials, construction, mechanisms, shape, colour, surface finishes and decoration of objects which are reproduced in quantity by industrial processes ... The industrial designer may also be concerned with the problems of packaging, advertising, exhibiting and marketing ...' [11].

Other descriptions have been proposed that are even broader in scope $[11,12]$. Critics of the profession question whether industrial design is in fact a distinct art; for example, Victor Papanek asserted: 'Design at present operates only as a marketing tool of big business' [13]. However, I believe my discussion above supports the claim that industrial design involves the aesthetics of visual fine art.

It remains to be shown that selected industrial products are suitable for exhibit in spaces ordinarily reserved for works of fine art. If industrial designers receive virtually the same training as painters, sculptors and design architects, then there is a rationale for displaying industrial products in museums. In the past, artists produced both artworks and utilitarian objects. Leonardo da Vinci, for example, made paintings and also carved buttons for a pope's mantle and designed machines. Walter Gropius, Moholy Nagy and Paul Klee were practicing artists and members of the Bauhaus School of Design. More recently, Arne Jacobsen exercised with equal facility the roles of painter, industrial designer and architect [14].

As in any of the visual arts, design refers to the planning stage of an artefact. Industrial designers provide sketches, drawings and models for the exterior design of products, though their role compared to sculptors encompasses a wider range of technical considerations. Norman Bel Geddes said: 'Charcoal, paint and clay, to be sure, are much more sensitive to the subtleties of individual expression than sheet metal ... on the other hand, steamships, airplanes, and radios present the same organic problems of design as do architecture, sculpture, and literature' [15].

These same artistic qualities can stimulate an aesthetic response in viewers, whether they are present in an artwork or in an industrial product. Seeing such a product in an art museum allows its artistic qualities to be appreciated, which is less likely to happen when it is in use or when it is shown in a museum of technology.

\section{SIMILARITIES AND DIFFERENCES BETWEEN INDUSTRIAL DESIGN AND THE FINE ARTS}

There is a larger issue to be examined. Only a small number of writings in English on the general topic of art and industry exists. Some of them are listed in Ref. 16. None 'of these writers, except Rudolf Arnheim [16], has examined extensively the relation of industrial products to fine art or the broad aesthetic questions posed by industrial design.

I wish to make some preliminary considerations of whether industrial design shares important theoretical concepts with fine art. Arnheim has provided persuasive examples to demonstrate that the major aesthetic concepts of expression, representation and style of fine art apply also to industrial products. He says: 'What we see ... is the expressive behavior of a pattern of visual forces. This pattern is related to the pattern of physical forces that constitutes the function of the object ... The correspondence is never complete. The external shape selects for visual presentation and interpretation only a few among the actual physical features of the object. These features may not be faithfully portrayed; they may be intensified or weakened... In fact the appearance may present features not physically contained in the object [16, p. 209]. These aspects of industrial products parallel certain features of sculpture and painting. And further, portrayal of function acquires aesthetic quality by serving symbolically for one's perception of the product' [Arnheim, 16, p. 209 and 17]. There was a product in the Marquette University Art and Industry Exhibition that I find supports Arnheim's point that industrial products can share qualities of fine art works. It was the processing artery shown in Fig. 7. Its order, balance and simplicity echo those of a piece of sculpture.

The Swiss sculptor Max Bill has pointed out 'Designers who realize new forms are consciously or unconsciously reacting to trends in contemporary art because it is in art that the intellectual and 


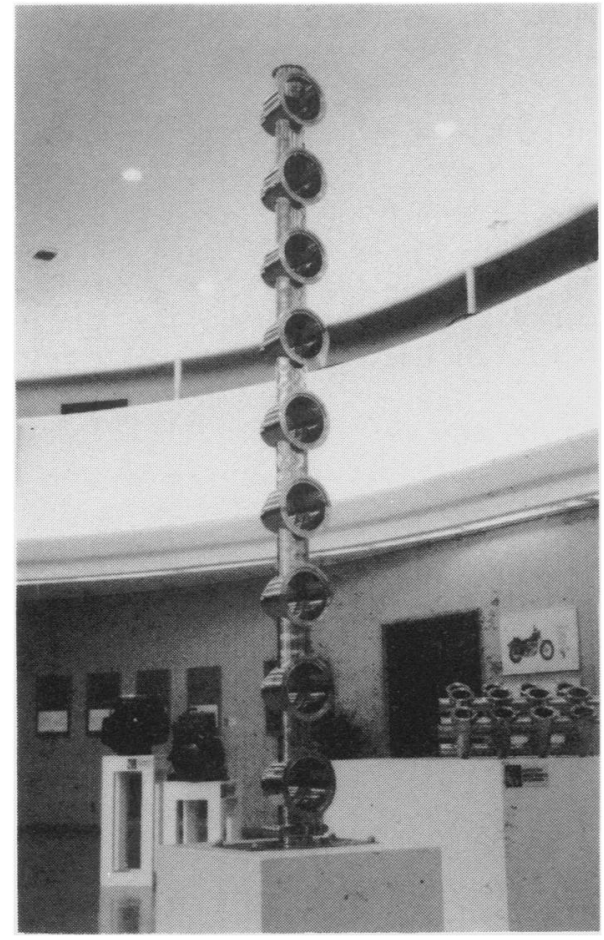

Fig. 7. View of processing arteries produced by Ladish Co., Milwaukee, WI, U.S.A. (Photo: A. Lovinescu, Shorewood, WI, U.S.A. (See Fig. 1)

spiritual currents of every epoch find their visible expression. Works of art may often be ridiculed or misunderstood when first produced but their almost immediate influence on every branch of design soon becomes apparent ... A glance from the sculpture of any of these phases to the best motorcar models brought out about the same time at once reveals the closeness of this involuntary connection between forms in art and forms in use, or, as we might call them, "product forms"' [18].

Papanek too shares the point of view that aesthetics and function are conjoined when he observes that an ordinary piece of wall board, whose primary use is to cover a wall, must also fulfill the aesthetic aspect of function by offering a variety of choices of texture and color $[13, \mathrm{pp} .18$, 19].

Despite the similarities between fine art and industrial design, there are obvious differences between them. That the differences consist simply in function and in appearance seems to me an inadequate estimate. Function often influences the shape of an industrial product, but, as in fine art, style evidently plays a role. Function does not preclude aesthetic appeal in a product, any more than the aesthetic value of an artwork precludes its use in a decorator's scheme. Nor does appearance in itself distinguish fine artworks and industrial products, as I pointed out above. Another example is the crane shown in Fig. 8, to which constructivist sculptures bear resemblance.

In regard to the differences it is worth recalling the description of industrial design given above: An

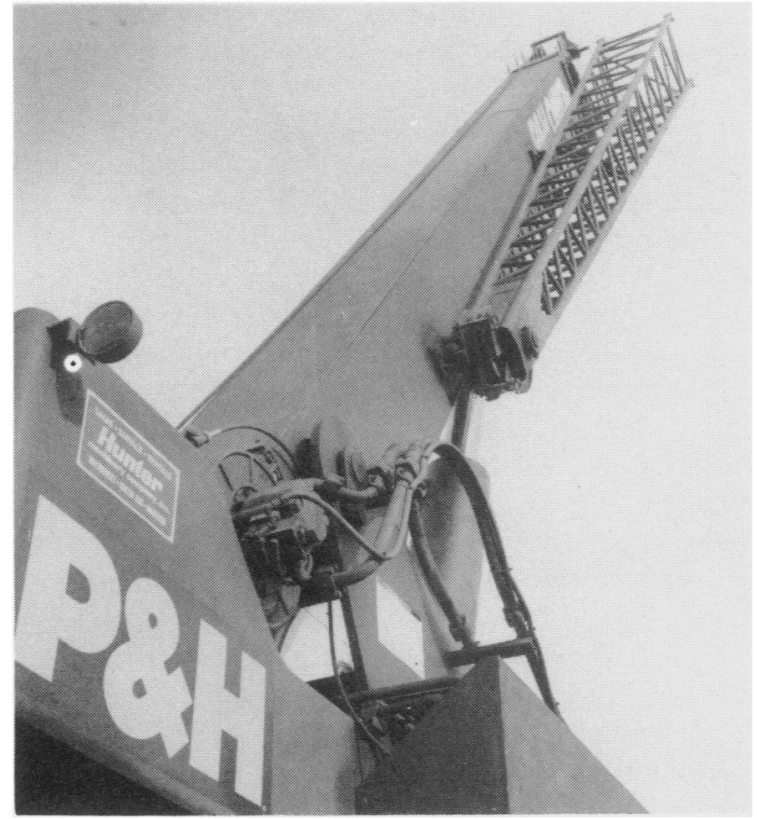

Fig. 8. View of the industrial crane produced by Harnishfeger Co., Milwaukee, WI, U.S.A. (See Fig. 1)

industrial product to be sold must work well and its external appearance is also important. Unlike the industrial designer, however, an artist is not obliged to make works that sell. If an industrial item is to be sold in large numbers as a consumer product, the responsibility for its design extends to the product's manufacturer and investors in the business and also to the buyers who expect efficient and safe products at low cost.

Reproducibility and low production costs are necessary constraints in industrial design, whereas uniqueness (except for lithographs, etc.) is a goal in the fine arts and cost of materials (with exceptions) and of an artist's time are generally not constraints. Since manufacturers in 'consumer' societies often deliberately make use of planned obsolescence to increase sales [Stevens, Ref. 2; Loewy, Ref. 3; 19, 20], industrial designers are pressed to make 'innovations', many of a trivial character. Of course unplanned technical obsolescence occurs in industrial products because of the application of new scientific knowledge, inventions, materials, etc. [21].

By contrast, artistic creativity and innovation does not render obsolete artworks of the past. Although artistic innovation in industrial societies has been particularly stressed since the 19th century, its most vigorous advocates, such as the futurists and constructivists, have not succeeded in their efforts to establish a point of view of the obsolescence of artworks of the past. Only the philistines in the commercial art market and self-serving promotors of 'new' art encourage this point of view. There is not a positive endorsement by the general public of innovation in the fine arts, as there seems to be in production of consumer products. On the other hand, in the commercial and curatorial art worlds 
innovative styles of fine art go in and out of fashion as do innovative designs of industrial products.

These considerations suggest that the principal difference between industrial design and fine art is one of direction. I have noted that appearance and function do not in themselves differentiate fine art and industrial products. Nevertheless, the primary orientation of industrial design is toward the manufacture of efficient low cost products, for example, of a crane. A crane is not intended for display, but to be used for lifting and transporting heavy objects. Its display in a museum is in a sense a violation of the end for which it has been constructed. However, an industrial designer may make its external appearance aesthetically satisfying without interfering with its functioning and increasing its cost.

Dewey characterizes the main difference between fine art and industrial products thus: 'The work of art ... unlike the machine, is not only the outcome of imagination, but operates imaginatively rather than in the realm of physical existences. What it does is to concentrate and enlarge an immediate experience. The formed matter of aesthetic experience directly expresses, in other words, the meanings that are imaginatively evoked; it does not, like the material brought into new relations in a machine, merely provide means by which purposes over and beyond existence of the object may be executed' [22].

Paintings and sculpture may, of course, have a function or utilitarian role, for they can serve as components in a decorator's scheme and as objects of commerce. However, they are most valued for aesthetic reasons when artists do not take these functions into account. On the other hand, an industrial designer is not permitted to impose aesthetic features on a product that would conflict with its use.

Although I have argued that appearance is not, of itself, a sufficient answer to the question of difference, it must necessarily be a dominant factor in any object whose appeal is visual. I have also argued that an artwork is directed primarily towards being displayed as an object of aesthetic contemplation. Appearance thus is the vehicle for aesthetic expression that enables viewers to comprehend formal qualities, iconography and subject matter of artworks. By contrast, the primary direction of industrial designers is to provide for the external appearance of a product an aesthetic appeal that complements its function.

\section{CONCLUSIONS}

My previous discussion has been based on the notion that artists and industrial designers alike are involved in the aesthestic qualities of, first, paintings, sculptures, etc, and second the external appearance of machines, machine parts, etc. It is important to ask, nevertheless, how new technology and the changing roles of artists and of industrial designers affect the relationship of fine art and industrial design. Electronics, computers, plastics, laser technology, xerography, cybernetics, bionics, etc. offer new challenges to artists and industrial designers. Will the application of these new developments produce parallel developments in fine art and industrial design? Clearly, industrial designers must cope with them, whereas artists need not, although there are quite a number who are using them to make artworks and operators of museums and commercial galleries are slowly learning to deal with them. Max Bill asserted that trends in the fine arts are the source of new forms in industrial design. Perhaps this was true earlier in the century, but I think his assertion can be called into question in view of the kind of artworks that are dominant in the art world at present and of the reverse influence of innovative industrial processes that artists adopt for their own purposes.

Changes in the role of industrial designers from specialist to generalist (Nelson), especially in regard to urban environmental problems, may have altered the relation of the fine arts to industrial design. However, the consciousness of whole environments, rather than of isolated parts, has also influenced artists in industrial societies, as readers of Leonardo are well aware. Earth Art, environmental installations, Performance Art and multi-theatrical artworks reflect this influence.

Accompanying advances in technology and the roles for industrial designers are changes in aesthetic values expressed in such terms as precision, smoothness and reproducibility, and new processes, techniques and materials. The traditional aesthetic values of order, balance and simplicity seem to be fundamental, and yet even these aesthetic values may need to be reexamined. A prevailing attitude of today's industrial designers is expressed by Archer who says: 'It is my personal belief that there are no Platonic values, no permanent rules of good design, which stand outside man' [11, p. 110].

The views of the pioneers of industrial design have been called into question. Papanek, for example, asserts that: 'The concept of what works well of necessity looks well, has been the lame excuse for all the sterile operating-room-like furniture and implements of the twenties and thirties' [13, p. 15]. Such designs are lacking in human value, he contends.

The recent expression of concern by industrial designers for social and moral responsibility points to another dramatic shift of values, as pointed out by Archer, Nelson and Papanek. Does this recent concern indicate an abandonment of past aesthetic values? Or does it signal a closer union of aesthetic values and social-moral values? At the moment in the U.S.A. there does not seem to be a heightening of social and moral concern among visual artists.

Where then has my investigation led? I believe it has provided a rationale for exhibiting selected industrial products in art museums and galleries because industrial designers are often also artists and they approach the design of products by relating aesthetics to their functional purposes. 
Furthermore, while industrial products are functional objects first and some of them for art displays second, artworks are intended primarily for aesthetic contemplation. It is not possible therefore to substitute industrial products for artworks without substantial loss of meaning. However, artists and the general public can benefit from the examination of the aesthetic features of industrial products in the reflective environment of a museum [23].

\section{REFERENCES AND NOTES}

1. I. Kant, The Critique of Judgement, J. C. Meredith, trans. (Oxford: Clarendon Press, 1952, 1969) pp. 41-90. See also H.-G. Gadamer, Truth and Method (New York: Seabury Press, 1975) pp. 39-90.

2. C. Carter and B. Stevens, Art and Industry: The Art of Industrial Design, exhibition catalogue (Milwaukee: Marquette Univ., 1979).

3. J. Gloag, Industrial Art Explained (London: Allen and Unwin, 1934, 1946. N. Pevsner, An Enquiry into Industrial Art in England (New York: Macmillan, 1937).

4. P. Johnson, Machine Art (New York: Museum of Modern Art, 1934) and (New York: Arno Press, 1969).

5. A. Reinhardt, Art and Art, in Esthetics Contemporary, R. Kostelanetz. ed. (Buffalo, NY: Prometheus Books, 1978) p. 213.

6. Industrial Design, in Encyclopedia Britannica (Chicago: William Benton, 1958) Vol. XII, p. 284.

7. D. J. Bush, Streamlining and American Industrial Design, Leonardo 7, 309 (1974), and D. J. Bush, The Streamlined Decade (New York: George Braziller, 1975).

8. Oxford Companion of Art, H. Osborne, ed. (Oxford: Oxford Univ. Press, 1970) p. 61.

9. C. Bradley, Design in the Industrial Arts (Peoria, IL: Charles A. Bennet, 1952) p. 32.
10. Quoted in H. Dreyfuss, Designing for People (New York: Simon and Schuster, 1955) p. 22.

11. L. B. Archer, Design Awareness and Planned Creativity (Ottawa: Department of Industry, Trade, Commerce and the Design Council of Great Britain, 1974) p. 19.

12. G. Nelson, George Nelson on Design (London: Whitney Library of Design, 1979) p. 8.

13. V. Papanek, Design for the Real World: Human Ecology and Social Change (New York: Pantheon, 1971) p. 91.

14. R. Hackney, Arne Jacobsen: Architecture and Fine Art, Leonardo 5, 107 (1972).

15. N. B. Geddes, Horizons (Boston: Little, Brown, 1932) p. 8. See also Ref. 7.

16. H. Read, Art and Industry (London: Faber, 1944); S. and M. Cheyney, Art and the Machine (New York: McGraw Hill, 1936); R. Arnheim, From Function to Expression, in Aesthetic Inquiry: Essays on Art Criticism and the Philosophy of Art, M. C. Beardsley and H. M. Schueller, eds. (Belmont, CA: Dickenson Publishing, 1967)pp. 199-214; G. Paulson, Design and Mass Production, in Design and Industry Association Quarterly, XVI (1931); Refs. 3, 4.

17. R. Arnheim, The Dynamics of Architectural Form (Berkeley: Univ. California Press, 1977) pp. 257-262.

18. M. Bill, Form (Basel: K; Werner, 1952) p. 11.

19. J. Oliver, Take Your Choice, catalog (New York: Cooper Hewitt Museum, 1979) p. 1.

20. T. Veblen, The Instinct of Workmanship and the State of the Industrial Arts (New York: A. M. Kelly, 1964); The Economic Theory of the Woman's Dress, in Essays in Our Changing Order (New York: A. M. Kelly, 1964); The Theory of the Leisure Class (Boston: Houghton, Mifflin, 1973). D. Bush, Thorsten Veblen's Economic Aesthetic, Leonardo 9, 281 (1976).

21. P. J. Grills, Form, Function and Design (New York: Dover, 1960) p. 11.

22. J. Dewey, Art as Experience (New York: Capricorn, 1934, 1958) p. 273.

23. My colleague, William Dooley, has provided helpful editorial suggestions to an earlier version of this article. 